\title{
The Importance of the Colour of the Cat: Ideology and Rationality in Chinese Rural Education after Mao
}

\author{
STIG THØGERSEN
}

\section{University of Aarhus}

"It does not matter whether the cat is white or black, as long as it is able to catch mice". This much quoted phrase of Deng Xiaoping's has become the symbol of the rational and pragmatic attitude of the Chinese leadership after the death of Mao Zedong and the fall of the "gang of four". During the decade of the Cultural Revolution, educational policy was presented in the media as the scene of constant class struggle between the proletarian and the bourgeois line. In Deng's China little is heard of class struggle. In the words of the new leadership the focus has shifted to economic construction because the "principal contradiction ... is that between the growing material and cultural needs of the people and the backwardness of social production". ${ }^{1}$

In accordance with this shift of focus, the leaders of the Deng era present themselves primarily as modernizers. While the "four basic principles" (Marxism-Leninism-Mao Zedong-thought, socialism, the proletarian dictatorship and the leading role of the Party) are still official state ideology (as it has been stressed ad nauseam in the campaign against "bourgeois liberalization" in early 1987) the Chinese as well as the foreign public are most often presented with an image of state and party leaders ruling rationally and pragmatically in the common interest of all strata of Chinese society. Just like the "line-struggle" model was formerly accepted by many Western observers as the most relevant conceptual framework for explaining Chinese politics, the new image of Chinese leaders tearing off their ideological blinkers to "seek truth from facts" is now widely accepted by the Western press as well as by scholars. ${ }^{2}$

The aim of this paper is to show that the post-1977 reforms carried out within Chinese education cannot be fully explained as pure, value-free adaptations of education to economic realities, ${ }^{3}$ but that the guiding ideology of the reformers as well as their need for support from the administrative, technical and intellectual elites have dictated much of the content of the reforms. Rural education in particular has been negatively influenced by some of the new central policies. To use the imagery of Deng Xiaoping, the cat has 
been chosen at least partly because of its colour and most of the mice are still alive and well.

Though rural secondary education shall be the emphasis of this paper, as problems present themselves most clearly at this level, other parts of the educational system will be touched on as well.

\section{Enrollment}

Before discussing the content of the reforms, we shall briefly look at their quantitative results. In primary school, enrollment has been little influenced by the reforms. In 1986, as many as $96.4 \%$ of all children in the relevant age group entered primary school. ${ }^{4}$ This is roughly equivalent to the enrollment ratio of ten years before $(1976: 96.0 \%)^{5}$ and shows that enrollment is on its way up again after dropping to $93 \%$ around $1980 . .^{6}$ The law creating nine years compulsory education, which was passed in 1986, is meant to maintain this high enrollment level, but it is worth noting that enrollment rose to its present heights not during the reform period but during the campaigns of the midsixties and of the Cultural Revolution period, when it went up from around $60 \%$ in the early sixties to $85 \%$ in 1965 and $95 \%$ in $1975 .{ }^{7}$ It is often claimed that enrollment figures of the seventies were grossly exaggerated, but the literacy statistics published from the 1982 census made it clear that the figures were not just empty boasting. ${ }^{8}$ If literacy can be used as a measure for the quality of education, these figures show that the most impressive progress in rural education was made during the "years of turmoil" from the outbreak of the Cultural Revolution to the late seventies. While about $30 \%$ of the age group that should have attended primary school in rural areas during the years from 1955 to 1964 are illiterate, illiteracy among the age group attending school between 1970 and 1979 was only found to be around $10 \%$. The situation of the girls in particular was improved during the seventies as a result of centrally directed campaigns. It is too early to draw conclusions about the most recent years, but it seems that the $90 \%$ literacy rate has at best been stabilized for the age groups entering primary school after 1978.

The dropout problem is serious already at the primary school level. According to World Bank statistics, only around 62\% of the 1979 school entrants completed the five years of primary school..$^{9}$ In 1985 , only around $60 \%$ of those in rural areas who did complete primary school were able to pass the final test, while the corresponding figure for urban students was $94 \% .{ }^{10}$ 
The literacy level of the present generation of rural primary school students can therefore not be expected to rise above the level reached in the seventies.

The above statistics can be summarized in the 9-6-3 formula, which is often used by Chinese experts to describe the state of education in rural areas: Out of ten school age children, nine enter primary school, six remain until its completion and only three pass the final test with satisfactory results. It should be added that the extension of primary education from five to six years could lead to an improvement in the long run. ${ }^{11}$ In 1983 less than $10 \%$ of those who completed grade five continued to grade six, ${ }^{12}$ but this may change as many schools have added an extra year since then. The above figures show, however, that the post-1978 reforms have so far made almost no contribution to solving the quantitative problems in Chinese rural primary education.

While the status quo has been preserved in primary school, enrollment in junior secondary school has dropped considerably since the reforms were first introduced. According to the World Bank, $63 \%$ of the relevant age group were enrolled in China's junior secondary schools in 1979 but only $46 \%$ by $1983 .{ }^{13}$ Since then enrollment has slowly been on its way up again, reaching $53 \%$ in $1986,{ }^{14}$ but as junior secondary education is almost universal in most of the larger cities, it must still be well below half of the children in rural areas who enter junior secondary school, probably only around $40 \%$.

The same kind of drop in enrollment has taken place at the senior secondary school level, but on a larger scale. According to Suzanne Pepper, this drop was initiated in 1978 by the issue of a set of "internal guidelines" ordering a reduction of student intake. ${ }^{15}$ As senior secondary school in most places has been extended from two to three years, absolute enrollment figures are not directly comparable, but the World Bank estimates that the percentage of the relevant age group enrolled in senior secondary schools dropped from $36 \%$ in 1979 to $16 \%$ in $1983 .{ }^{16}$ Though absolute enrollment figures now show an upward tendency because of the extension from two to three years, it seems that the enrollment ratio has in fact continued to drop as an official Chinese source mentions a ratio of only $13 \%$ of the age group for $1986 .{ }^{17}$ The fall in enrollment has been particularly evident in the villages. While rural schools enrolled $66 \%$ of all senior secondary school students in 1977 , their share had fallen to $42 \%$ in 1981 and to $29 \%$ in $1984 .{ }^{18}$ I have not come across more recent figures, but there is no sign that the position of the rural schools is strengthening at this level.

Even when we take into consideration that both primary and senior 
secondary schools have been extended by one year each during the reform period, children in rural areas thus seem to attend school for fewer years on average now than they did before the reforms. What sort of pragmatic rationality lies behind this cutback? Two arguments are often put forward in this connection. First, the reduction is said to have been necessary in order to raise the quality of education and, secondly, it is explained as part of a readjustment of secondary education, whereby more students are being directed into vocational track schools. In the following we shall look closer at these two arguments.

\section{The Quality of Rural Education}

According to reform leaders, enrollment increased during the early seventies at a much faster rate than China could afford. Schools were set up without qualified teachers, teaching materials or even tables and chairs, and the quality of teaching consequently dropped to an unacceptably low level. According to official statements, the present level of enrollment represents a readjustment of the educational sector to China's economic capability, and the human and material resources freed by the cuts made particularly in senior secondary education have been spent on strengthening schools at the lower levels.

There is little doubt that the quality of many rural schools was indeed very low before the reforms, but have the resources made available after the closing of huge numbers of secondary schools really been spent on improving the quality of education in the remaining rural schools? While the quality of education is difficult to measure objectively, it is possible to get an impression of how it is judged by students and parents by looking at the schools' dropout rates, which according to many reports have reached alarming proportions in recent years, particularly in junior secondary schools.

According to a recent Chinese survey of an economically healthy county in Heilongjiang Province, which has popularized primary education, only around $40 \%$ of elementary school leavers in that area continue their education in junior middle school, and among these students the dropout rate has risen dramatically during the last couple of years. Of those entering junior middle school in 1979,44\% did not graduate three years later. For the next year of students the dropout rate went up to $67 \%$, and of the students entering middle school in 1981 as many as $72 \%$ had dropped out before 1984 . This phenomenon was, according to the report, quite new. During the decade of the Cultural 
Revolution, dropout rates had been only slightly above $20 \%$. The large majority of the dropout students left school during their second year, and had thus had ample time to realize what secondary school was like. ${ }^{19}$ The World Bank dropout rate estimates are lower though still considerable at this level: $12 \%$ between grades one and two and $22 \%$ between grades two and three, ${ }^{20}$ but these are average figures for the $1979-83$ period, and they furthermore include city schools, where few students drop out, as they know that they will be unable to find a job without a junior middle school certificate. In rural areas the dropout problem does seem to be massive. Several recent reports from different provinces have spoken of dropout rates from rural junior secondary schools of around $50 \%,{ }^{21}$ and rates of $40-50 \%$ have been officially admitted to be quite common even for whole districts (including towns). ${ }^{22}$

The alarming dropout rates can be partly explained by the influence of the contract system in agriculture, where individual families are allowed to sell surplus products from their plots and increase their income by engaging in sideline productions. As it is mainly labour intensive production methods that are used, many peasants could be tempted to order their children (girls, in particular) to leave school in order to help in the work or look after younger children at home. This is, for example, how the World Bank explains the decrease in students' attendance in rural areas. ${ }^{23}$ It is doubtful, however, that this is really the most important source of the problem. The Heilongjiang survey mentioned above finds that the contract system can only bear a small part of the blame for the high dropout rates, as most families in the area under survey already had ample labour power. The reason, according to the survey, is rather to be found inside the schools, where teachers concentrate only on the students who have a chance of passing the entrance examination to senior secondary school and ignore the rest, a problem discussed below. The same trend is found in a Hunan survey, which claims that neglect from the teachers and lack of motivation for study due to low marks account for $55 \%$ of all dropout cases in the schools surveyed, while less than half of the cases can be explained by one or more objective factors such as high tuition fees, long distances to school and parents' need for children's participation in production. ${ }^{24}$ In most cases several of the factors mentioned are probably jointly responsible, and many reports put most of the blame on the contract system. However, the Chinese debate on the subject reflects a growing conviction that the main reason for peasant children's escape from middle school is the fact that they feel they benefit very little from the teaching taking place there, or, in other words, that the quality of education, as they conceive it, is too low. 


\section{Effects of the Elite Strategy}

One of the main reasons why the quality of at least rural secondary education is still so low is to be found in the many negative side effects of the examination system, or to use a Chinese phrase, in the "onesided pursuit of transition rates" (pianmian zhuiqiu shengxuelü), a phrase portraying the situation in most schools after the introduction of the university entrance examinations in 1977. The syndrome shall just be briefly summarized here: The return of selection of university students through competitive examinations, the scarcity of institutions of higher education, and the permanent high status job that a university education guarantees all combine to create a situation of fierce competition between students, parents, teachers and schools for access to universities. To place their own students better in this competition, local authorities (encouraged by central directives) have set up an elite sector inside the educational system, the so-called key-schools and key or "fast" classes, where the most competent teachers, the highest scoring students and the majority of economic resources have been concentrated. Rural counties have carried this strategy to even further extremes than cities, because their backward conditions force them to highly concentrate their resources, if they want to send just a few of their young people to university. This trend is reinforced by the traditional Chinese respect for exams and degrees, and by the traditional idea that the purpose of studying is to raise one's own social position to that of a state bureaucrat. The concentration on a small elite further leads to the neglect of and general disillusion among the remaining students, who in great numbers choose to stop attending classes. Their schools often directly encourage them to drop out, as this allows them to allocate even more resources to the elite on which their prestige and often also economic welfare is based. In addition they can then improve their transition rate (the percentage of graduate students who get accepted by schools at the higher level) if students who would not have been accepted by a higher level school anyway drop out before the final examination. The "transition rate syndrome" does a lot to explain what happened to the economic and human resources set free by the enrollment cut: They were largely spent on the training of the relatively small number of students who had a chance of winning a place in a higher level school.

The irony of the situation is that while the few rural students who make it into university are the pride of their family, their school and their county, they actually represent a loss to their local community, because they rarely return to 
the countryside after graduation. In $\mathrm{Yi}_{\mathrm{i}}$ County, a poor county in Liaoning Province, 1400 students qualified for higher education from 1977 to 1986, an impressive transition rate of $18 \%$. But only 205 university graduates, $15 \%$ of the students who left, were allocated work in the district during the same years, and most of these were school teachers, who rank lowest in prestige among graduates. ${ }^{25}$ In the poor, mainly rural, province of Guizhou a similar "brain drain" is reported to take place - the return rate of university students is here $40 \%$. ${ }^{26}$ This loss is, however, partly compensated for by the students' feeling of loyalty towards their home district. This can potentially benefit the local community if the students later advance to influential posts.

The increase in educational expenditures, a highly publicized part of educational reforms in recent years, has also gone primarily to the elite. As pointed out by Stanley Rosen, the funding of basic education is now left to local initiative, while central investments go to key institutions mainly at the tertiary level. ${ }^{27}$ Furthermore, most of the increase that has taken place has gone to raise the wage level of the teachers, a much needed step, but one which does not immediately improve conditions for the students. In Sichuan Province, for example, $90 \%$ of the increase in educational spendings from 1984 to 1985 was spent on higher salaries, $6.7 \%$ on construction work and only $3.3 \%$ for pedagogical purposes. Though an increase in total expenditure per student was measured in primary and secondary education that year, salaries ate up so much that the sum per student left for teaching purposes actually fell, even without accounting for inflation. ${ }^{28}$

The pedagogical and economic concentration on elite education is, however, not the only way in which the "transition rate syndrome" has negatively influenced rural schools. Just as important is the total adaptation of teaching methods and content to the demands of the examination system. What is taught is not what the students need to know in order to fill their future roles as citizens and producers, but what they must learn in order to pass the next exam. Chinese educators have repeatedly pointed out that memorizing equations and formulas will be of little help to rural students in their later lives as peasants. The power of the examination system (and of the Chinese tradition for rotelearning) has, however, been too strong, and, as a recent wave of very critical reports on rural education in Renmin Jiaoyu (People's Education) and Jiaoyu Yanjiu (Educational Research) shows, ${ }^{29}$ the authorities have had little success in trying to change the situation.

It can be concluded that the post- 1978 educational reforms have meant that fewer rural students receive secondary level education, while the quality of the 
education offered still seems to be far from satisfactory in the eyes of the rural population, mainly due to its being fundamentally out of touch with the needs of the villages. To quote an editorial comment in Educational Research on a devastating criticism of rural education in Heilongiiang: "The social benefit of rural secondary education is currently low. When secondary school graduates return to their villages, their ideological consciousness, academic knowledge, productive skills and work ability lag far behind the demands of the political and cultural life of the villages and of the need to develop commodity production" ${ }^{30}$ Post-1978 reforms may have raised the quality of elite education, but secondary education in rural areas is today, ten years after the first reforms, in a state of acute crisis.

\section{The Vocationalization of Rural Secondary Education}

The enrollment cut was never presented in the Chinese media as a reform per se. It was mentioned in educational magazines under the comprehensive headline of "reform of the structure of secondary education", and in this context it was overshadowed by the intense interest in the vocationalization of senior secondary education. This program has in a few years transformed thousands of general secondary schools into vocational schools and has radically changed the balance between general and vocational education. The proclaimed aim is to let vocational schools enroll $50 \%$ of all senior secondary level students by 1990 .

The arguments for the vocationalization reform again appear to be pragmatic and rational: The economic modernization drive demands an increasing number of skilled workers, middle level technicians and peasants with a better knowledge of agricultural technology. As tertiary education is able to absorb only a small fraction of all senior secondary school graduates, leaving the rest to find their place in production, China now prefers, so the argument goes, to provide the latter group with some practical, vocational skills while they still are in school, thereby improving their chances offinding a job aftergraduation. This should be seen in contrast to the Cultural Revolution decade, where, according to the present leaders, almost all formal vocational training in schools was stopped.

In quantitative terms the reform has been a success. The number of students in "skilled worker training schools" and "secondary specialized schools" was beginning to rise already before 1978 , and this development further accel- 
erated in the early eighties. The number of students in "skilled worker training schools", which are under the sector ministries and train future skilled workers mainly for industry, rose from less than 9,000 in 1971 to 221,000 in 1976 and increased still further after the fall of the "gang of four" to 628,000 in $1984 .{ }^{31}$ "Secondary specialized schools", responsible for the training of for example primary school teachers, hospital nurses, accountants and medium level technicians in industry and agriculture, have raised their enrollment from 147,000 in 1971 to 690,000 in 1976 and further to $1,332,000$ in $1984 .{ }^{32}$ By far the largest enrollment expansion, however, has taken place in "vocational middle schools" and their rural counterparts, the "agricultural middle schools". These types of schools were very common before the Cultural Revolution, particularly in rural districts, but when middle schools reopened in the late sixties, the division between general and vocational schools was abolished. Vocational secondary schools did not reappear in the statistics again until 1980, but by 1984 they already had an enrollment of $1,745,000$ students. $^{33}$ If the latest statistics are reliable their enrollment reached $4,800,000$ students in $1986 .{ }^{34}$

In the cities, vocational middle schools train people for a number of different jobs in industry and particularly in the service sector, where most of the work force has traditionally been either unskilled or trained on the job-kindergarten teachers, tailors, radio repairers, waiters, etc. Curriculum planning is decentralized and flexible, costs are low, only around one third of the cost per student of a "skilled worker training school", 35 and by cooperating closely with enterprises in their vicinity schools are often able to train types of manpower which are in demand locally. ${ }^{36}$ It is debatable whether this kind of specialized training is a better preparation for work in industrial and service trades than general education, ${ }^{37}$ but judging from the Chinese debate and from my own visits to such schools in different provinces, vocational schools in the cities do seem to have found a role for themselves.

In rural areas, however, the vocationalization process has been more complicated and its logic is harder for the observer to grasp. Seen in the perspective of the last twenty years it seems more precise to talk about a devocationalization reform which began in 1978 and which is now being partly reversed.

Before 1978, China's rural schools had won international recognition for their ability to adapt curriculum and teaching methods to local needs and conditions. Mao's directives on combining theory with practice and integrating study and productive labour were praised by educators in many Third World countries as well as in the West. ${ }^{38}$ Historically the Yan'an period, the 
years of the Great Leap Forward and the decade of the Cultural Revolution are especially noted for implementing these principles. "Half-work half-study" schools were established to lighten the economic burdens of schooling on the peasants, and the content of all school subjects was adapted to local conditions and to the needs of local agricultural production. This was, at least, the picture presented in official Chinese propaganda during those periods. There is much evidence, not only from the present leaders, who have their own reasons for discrediting all Cultural Revolution practices, but also from ordinary village school students of the Cultural Revolution decade which shows, however, that "theory" (which meant book learning) and practice were rarely combined in real life. Too much time was often spent on memorizing quotations from the works of Chairman Mao and "practice" frequently just meant simple manual labour from which students learned no new production skills. Still, it is important for later developments that rural schooling was described in official propaganda as not only a political but also a professional preparation for living the adult life of a Chinese peasant. In this sense, rural schooling was perceived as vocational education for all village children. It was possible for rural students to follow other careers and even to go to university, but they were to qualify through hard work and political devotion, not only through achieving high academic merit, and they all had to take classes in agricultural subjects and do manual labour.

The post-1977 reforms introduced academic admission criteria to higher education, and as a consequence the curriculum was unified nationally, with all teaching materials being centrally authorized. The unification of the content of education was a precondition for holding nationwide examinations, but it meant that adaptation to local needs became almost impossible. Rural and urban students, future peasants, future workers and future nuclear scientists all had to study identical textbooks. These were primarily geared towards the needs of the last group, and the tight time schedule left no time for practical work.

As the new general school curriculum evidently was irrelevant to many students, particularly at secondary school level in rural areas, many general secondary schools were now transformed to vocational schools. In most counties one high quality secondary school was selected as a county or provincial level key school, a few schools of reasonable standard remained ordinary (i.e. non-key) general schools, a number of mediocre schools were transformed to agricultural secondary schools, while the majority were either turned into junior secondary schools or simply closed down. In agricultural 
secondary schools, students spend half of their time studying general subjects and the other half on subjects directly related to agriculture and on practical work. Already in 1981, fifty-two different specialities inside agriculture were being taught. After graduation, students should be qualified to either work as basic or medium level agricultural technicians (tractor drivers, basic level veterinarians, etc.) or to establish "specialized households" (zhuanye hu), where they could utilize a speciality studied in school, such as fish breeding or fruit growing e.g. This is how the system ideally works. It is often stressed, however, that the principle of half-work-half-study should be implemented in these schools, and in lower quality schools this seems to be done in the same way as in earlier decades: students go to school half of the time and do ordinary manual labour only loosely related to their studies during the other half.

Agricultural secondary schools have encountered many problems. As it is normally schools of a rather low quality that are transformed, they often lack qualified teachers and relevant teaching materials. Some graduates have difficulties finding jobs, and the social prestige of the schools is low. However, the most fundamental problem, which is only now beginning to attract attention in China, is that the establishment of agricultural schools has been used to justify the de-vocationalization of general track schools. Almost all vocational and agricultural schools have been established at senior secondary school level, but only $10-15 \%$ of a particular age group receive schooling at this level, and at most half of these are in the vocational tracks. This means that over $90 \%$ of all rural students follow a curriculum throughout their educational career that is designed to meet the needs of the few, mostly urban students striving for an academic career. It is striking how present criticisms of this phenomenon resemble, not in form but in content, Cultural Revolution attacks on what was called, in the more militant language of that time, 'Liu Shaoqi's black line in education". In mid-1986, for example, a Shanxi official described the situation in rural schools as follows:

First of all, the whole educational system works for the sake of the university entrance examinations. Curriculum, content and admission practices in rural primary and secondary schools have not yet been changed. Teaching materials serve the purpose of preparing students for advancing to the next level of education. Even students who go to junior and senior secondary school feel that their education is of no use if they cannot go to university. We must add some agricultural knowledge to the textbooks used in the senior years of primary school and in secondary 
school, so that students know a bit about what is going on around them in agricultural production.... At present, the large majority of village secondary school students want to "jump out through the village gate" (tiao nong men) and leave the countryside. If schools provided them with some basic skills that would enable them to change the backward conditions of their village fewer people would want to leave.... ${ }^{39}$

Other writers equally familiar with the situation in rural schools have pointed out, subject by subject, how the content of the textbooks used is totally out of touch with students' lives and needs and therefore also very difficult for the students to comprehend. ${ }^{40}$

Seen in this light, the vocationalization reform in rural schools must be regarded as a defensive measure meant to limit the negative consequences of the "de-vocationalization" wave sweeping through China's village schools in the wake of the post-1977 reforms.

\section{Ideology and Educational Reform}

The present crisis in rural education cannot be explained without considering the ideology that the reform leaders have been promoting. Two aspects deserve particular attention: The attitude to China's educational history in the period of the People's Republic and the strengthening of meritocratic values in Chinese society after 1977.

An important part of the power base of the post-1977 Chinese leadership is the group of cadres forced from power during the Cultural Revolution and later rehabilitated. Deng Xiaoping himself reappeared as vice-chairman of the Communist Party in 1977, and the highest ranking target of the Cultural Revolution, China's president up to 1967, Liu Shaoqi, was posthumously rehabilitated in the spring of 1980. When Hua Guofeng in 1981 was replaced as Party chairman by $\mathrm{Hu}$ Yaobang it marked the final victory of the people associated with the pre-1966 period over the Mao loyalists. The political verdict was thus spelled out clearly: The Cultural Revolution had been a disaster to China's development in all fields, while pre-1966 policies were "basically" correct and the period before the Anti-Rightist Campaign was pictured as a paradise lost.

On the educational front a parallel development could be observed. One of the first signs of change was a vehement attack on the so-called "two esti- 
mates". During the Cultural Revolution, it was now said, the pre-1966 educational line was described as bourgeois and "black", and the majority of the intellectuals were seen as enemies of the people. Both of these "estimates" were fundamentally wrong. Chinese educational policies had been basically correct even in the most "Liuist" period in the early sixties, and the large majority of Chinese intellectuals had been loyal to the Party and to socialism. This viewpoint led to the rehabilitation of educational cadres and teachers criticized during the Cultural Revolution and the Anti-Rightist Campaign and to a positive reevaluation of the educational policies of Liu Shaoqi.

Concurrently, "new-born things" and model units of the Cultural Revolution came under attack, and so did the heroes of that period. Zhang Tiesheng, who had become famous by handing in a blank examination paper as a demonstration against the examination system, was now called "an ignorant, reactionary clown" by Deng Xiaoping. ${ }^{41}$

The rehabilitation of pre-1966 leaders and policies and the corresponding total rejection of all phenomena associated with the Cultural Revolution have thus been prominent features of the political and ideological development since 1977. This does not mean, of course, that the last ten years simply have been a return to the pre-Cultural Revolution state of affairs. Many policies are genuinely new, but it has been of major importance to the rehabilitated cadres that the pre-1966 period, where they last held political power, is seen as a prosperous and harmonious time, while the Cultural Revolution, when the same cadres suffered political and personal humiliation, is remembered as an unjustifiable and disastrous event. It was only by making this ideology widely accepted that they could regain their former power and prestige, and only this interpretation of history was therefore acceptable to the highly heterogeneous group of dethroned cadres.

In the educational field the pressure on the post-1977 leadership to return to the legacy of the period before the "ten years of turmoil" and totally reject the achievements and experiences of the Cultural Revolution was even stronger than in other spheres, because the teachers, or at least a considerable part of them, had been through the same or even worse sufferings and humiliations as the cadres. To secure their cooperation it was necessary to convince them that the new leadership was fully on their side and intended to correct all wrongs against them.

The campaign style of Chinese politics thus stood in the way of a careful and objective assessment of both the positive and negative aspects of the educational experiments that took place during the Cultural Revolution. The 
Cultural Revolution had had such a tremendous impact on its victims that they, once back in power, were determined to wipe out all traces of the preceding decade. This led to a tabooing of a number of problems that now have to be readdressed, particularly the question of how to make education relevant to rural youths.

In some fields, however, the post-1977 educational reforms have moved beyond the limits of the pre-1966 model. Making academic tests and exams the all-important selection criteria is one such example. The new method of selection was of prime importance to an indispensable part of the constituency of the new leaders: the technological and intellectual elites. To these groups it was intolerable that access to the higher levels of the educational system and thereby to the top of the job hierarchy should any longer be based on political and class criteria and thus be controlled by Party cadres. They demanded the introduction of academic selection criteria that would give their children an even opportunity in competition with the offspring of other social groups. ${ }^{42}$ Though this reform was probably welcomed by the majority of parents who had lost faith in the Cultural Revolution system, where nepotism seems to have been widespread, ${ }^{43}$ it also led, as we have seen, to severe problems in rural areas, where it merged with traditional Chinese attitudes towards education to produce an atmosphere filled with ruthless competition and uninspiring rote learning. Rural youths have not increased their chances of gaining access to university after the introduction of the new selection criteria, ${ }^{44}$ but they have paid much of the price for them.

\section{Conclusion}

Loyalty to pre-1966 educational models, distaste for all policies associated with the Cultural Revolution, total acceptance of meritocratic arguments in the discussion on the selection of "talented personnel", and extensive consideration for the interests of the elite seem to be important obstacles to a more rational attitude on the part of the Chinese leaders to the problems facing rural education. One encouraging fact about this process is, however, that almost all the problems mentioned in this paper are now under open and lively discussion in Chinese educational circles in a way unprecedented in the 
history of the People's Republic. This could lead to the emergence of a new type of "rationality" able to incorporate the experiences of the past forty years and the viewpoints and demands of the rural population.

Stig Thogersen is an Associate Professor, Institute of East Asian Studies,

University of Aarhus

\section{NOTES}

1 Resolution on CPC History (1949-81)

(Bejing: Foreign Languages Press, 1981) p. 76.

2 "Pragmatism rules the day", was, to take just one of the most recent examples, the sub-headline of Newsweek's latest "Special Report" on China (No. 36, September 8, 1986). Lucian W. Pye, in his article "On Chinese Pragmatism in the 1980s", The China Quarterly, No. 106 (June 1986), pp. 207-234, points out that academic circles have also accepted the idea that the new leadership is pragmatic and rational. Pye's view is that several cultural factors set limits to this pragmatism, whereas my objective is rather to point to ideological and socio-political factors.

3 More detailed discussions of recent developments in education can be found in Ruth Hayhoe (ed.), Contemporary Chinese Education (London: Croom Helm, 1984). The relation between education and economy is discussed in Marianne Bastid, "Chinese Educational Policies in the 1980s and Economic Development", The China Quarterly, No. 98 (June 1984), pp. 189-219.

4 Guangming Ribao, February 22, 1987, p.3.

5 Zhongguo Jiaoyu Nianjian 1949-1981 (Beijing 1984), p. 1024.

6 lbid.

7 Ibid.
8 Illiterates and Semi-Illiterates as Percentage of Rural (xian) Population

\begin{tabular}{lllrr}
\hline $\begin{array}{l}\text { Age } \\
\text { in } \\
1982\end{array}$ & $\begin{array}{l}\text { Primary } \\
\text { School } \\
\text { Years }\end{array}$ & Total & Male & Female \\
\hline 12 & $1977-82$ & 10.53 & 5.75 & 15.60 \\
13 & $1976-81$ & 10.86 & 5.76 & 16.25 \\
14 & $1975-80$ & 10.97 & 5.77 & 16.50 \\
$15-19$ & $1970-79$ & 10.55 & 4.72 & 16.55 \\
$20-24$ & $1965-74$ & 16.92 & 6.70 & 27.46 \\
$25-29$ & $1960-69$ & 25.89 & 11.01 & 41.72 \\
$30-34$ & $1955-64$ & 29.78 & 15.02 & 45.64 \\
$35-39$ & $1950-59$ & 31.45 & 15.93 & 48.66
\end{tabular}

Source: Zhongguo 1982 nian renkou pucha $10 \%$ chouyang ziliao, dianzi jisuanji huizong (Ten percent sample survey of the Chinese 1982 census: a computerized selection), Beijing 1983, Table 29, pp. 320-21

9 World Bank, China: Long Term Issues and Options. Annex A: Issues and Prospects in Education, 1985, p. 57.

10 Jiaoyu Yanjiu, 1986, No. 8, p. 72.

11 There is presently a debate going on in China as to whether the nine years of compulsory education should consist of six years of primary school and three years of junior secondary school or rather be a five plus four system with the extra year of junior secondary school spent on vocational subjects. The last model is being practised in some rural areas, but the former is still by far the 
most common. See for example Jiaoyu Yanjiu, 1986, No. 8, for a defense of the five plus four model.

12 World Bank, op.cit. p. 57.

13 Ibid., p. 7.

14 Renmin Jiaoyu, 1986, No. 11, p. 21.

15 Suzanne Pepper: China's Universities (Ann Arbor, Mich.: University of Michigan Press, 1984), p. 35.

16 World Bank, op.cit., p. 8.

17 Renmin Jiaoyu, 1986, No. 11, p. 21.

18 Zhongguo Jiaoyu Nianjian 1949-1981, p. 1006 and Zhongguo Jiaoyu Nianjian 19821984, p. 69. It should, however, be kept in mind that only $9 \%$ of senior secondary schools were placed in rural areas in 1965 (ibid.) Seen in this perspective rural schools have far from lost all they gained in the early seventies.

19 Jiaoyu Yanjiz, 1985, No. 8, p. 33 ff.

20 World Bank, op.cit., p. 8.

21 See Jiaоyu Yanjiu, 1986, No. 10, p. 17; Renmin Jiaoyu, 1986, No. 11, p. 9; Zhongguo Jiaoyu Bao, May 21, 1987, p.2.

22 Renmin Jiaoyu, 1987, No. 5, p. 2.

23 World Bank, op.cit., i-ii.

24 Zhongguo Jiaoyu Bao, May 21, 1987, p. 2

25 Renmin Jiaoyu, 1987, No. 5, p. 29.

26 Børge Bakken, "Bakvendtreform i kinesisk utdanning" (Backward Reform in Chinese Education), Materialisten, No 3, 1986, pp. 7-38.

27 Stanley Rosen,'Recentralization, Decentralization and Rationalization: Deng Xiaoping's Bifurcated Educational Policy", Modern China, Vol. 11, No. 3 (1985), pp. 301-346.

28 Jiaoyu Yanjiu, 1986, No. 9, pp.17-22.

29 In Renmin Jiaoyu, 1986, no. 7/8, a discussion on the question "How can rural primary and secondary education meet the needs for development of agricultural production" was initiated. In Jiaoyu Yanjiu, 1986, No. 4, the theme of discussion was phrased "Reorienting Educational Thinking and Defining Educational Goals" (from 1986, No. 4). Both discussions are still running (by spring 1987) and give excellent insights into the seriousness of the problem.

30 Jiaoyu Yanjiu, 1986, No. 10, p. 17.

31 Zhongguo Jiaoyu Nianjian 1949-1981, p. 188 and Statistical Yearbook of China 1985, p. 586.

32 Zhongguo Jiaoyu Nianjian 1949-1981, pp. 982-83 and Statistical Yearbook of China 1985, p. 587.

$33 \mathrm{Ibid.,}$ p. 586.

34 Guangming Ribao, February 22, 1987, p. 3. This figure is official but appears to be exaggerated or, perhaps, the definition has been changed.

35 Jihua Jingji Yanjiu, 1982, No. 10, pp. 32 36.

36 For a detailed discussion of the different types of vocational schools see Joachim Münch \& Matthias Risler, Vocational Training in the People's Republic of China. Structures, Problems and Recommendations (Berlin: CEDEFOP, 1987).

37 Even the World Bank, which supports the vocationalization program, is sceptical on this point. See World Bank, op. cit., pp. 28-29.

38 Ronald P. Dore, for example, in his influential study, The Diploma Disease. Education, Qualifications and Development (London: Allen \& Unwrin, 1976), saw the Chinese model as superior to other Third World educational systems.

39 Renmin Jiaoyu, 1986, No. 7/8, p. 14.

40 Renmin Jiaoyu, 1986, No. 11, p. 11.

41 Selected Works of Deng Xiaoping (19751982) (Beijing: Foreign Languages Press, 1984), p. 107.

42 Once implemented, the new system actually seems to favour the children of intellectuals and cadres over other groups. See Suzanne Pepper, op.cit., particularly pp. 107-116 and Stig Thegersen, "Chinese Senior Middle School in a Social Perspective: A Study of Yantai District, Shandong Province", The China Quarterly, No. 109 (March 1987), p. 72 100. 
43 Jonathan Unger's interviews with Canton youth, for example, show how widespread corruption and nepotism was during this period. See Jonathan Unger,
Education Under Mao (New York: Columbia University Press, 1982), pp. 193 ff. 44 See note 41 . 